\title{
Aesthetic Pursuit of Commercial Window Design
}

\author{
Ziqi Yang \\ School of Arts \\ Huzhou Normal College \\ Huzhou, Zhejiang, China 313000
}

\begin{abstract}
Commercial window is a practical art which has practical function and aesthetic value. It is not only an important part of the beauty of the appearance of the whole commercial building, but also the elements of the urban landscape space. This paper discusses the beauty of space image, the beauty of creative expression, the beauty of information presented, the beauty of environmental dependence, and put forward the importance of aesthetic theory in the design practice.
\end{abstract}

Keywords - commercial window; aesthetic theory; space; visual; aesthetic

\section{INTRODUCTION}

Commercial window is used to show the samples of glass cabinets by shops in the street or in the mall corridor. In this space, goods in kind, brand connotation, corporate culture, humanistic care and social values and other aspects have been fully demonstrated, which is described as a limited form but unlimited contents. It not only attracts customers, but plays to beautify the building elevation, rich street landscape, render the commercial atmosphere, guide the trends of consumers. Commercial window design is an important combination of commercial building and interior design, so in consideration of the environment, integrity and the principle of the times, we should also follow its unique aesthetic pursuit.

\section{ECONOMIC VALUE AND SOCIAL VALUE OF COMMERCIAL WINDOW}

Commercial window is the "face" and "eye" of the shops, which has high economic value and social value. A good design of commercial window not only reflects a shop's marketing characteristics, brand and visual beauty, but shows a city's economic level and people's aesthetic level. Commercial window is an irreplaceable way to show the brand and commodity attributes, which is also called "Point of Purchase Advertising" "Fig. 1". Commercial window design is the closest activities with market economy, and its design is directly related to the sales performance of the goods. Meanwhile, it is not only a vital part of the beauty of the appearance of the whole commercial building, but also a element of the urban landscape. So, as a store manager and operator equipped with economic consciousness of modern market should carefully consider all the designs of window when does shop designs, presenting the charm of the brand and enhancing the strength and competitiveness of the store with colorful and diverse forms of window design. Of course, a local and manager with modern consciousness expect to beautify streets and improve city's environment by excellent window design.

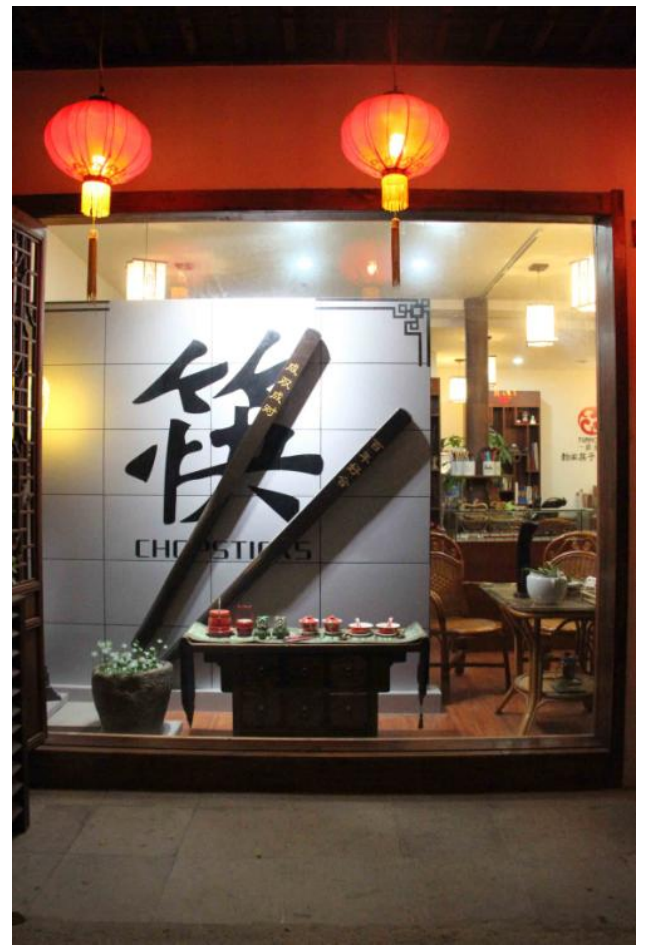

Fig. 1. Commercial window is the "Point of Purchase Advertising"

\section{GUIDING COMMERCIAL WINDOW DESIGN IN AESTHETIC THEORY}

With the development of Chinese market economy and modernization of city, downtown business district, commercial street, commercial window design has been increasingly emphasized. Under such a social background, the appearance of excellent window improves shop's visual aesthetic effect, attracts customers, stimulates commodity, requires obvious economic benefit, and also decorates city, beautifies city, enriches landscape, and acquire preferable social benefit. ${ }^{[1]}$ The design of vulgar and poor quality of the window however can be seen everywhere, not only caused a great waste of resources, but also affect the economic benefits and social benefits of the commercial window. Therefore, creating a modern window design with high quality and high aesthetic level needs the continuous exploration and innovation of 
designers, also needs aesthetic theory of staff to guide the design practice.

Commercial window design is a highly integrated design work, which purposefully and prepensely propagandizes the image of shop thorough the way of leading, advertising and communicating, engaging in mutual supplement or two-way reinforcement design of the space environment for meeting the need of promoting the image. It uses a variety of information transmission to fully display store's business content and corporate brand information to customers by creating theme phenomenon of window space, with a view to the comprehensive art design activities carrying out the customers' physiological, psychological and behavioral awareness or intrinsic resonance. Modern window designs has been different from the past which focus on single functional status, but on cultural characteristics to promote the design of human spirit needs. ${ }^{[2]}$ In the design process, designers must clear the aesthetic pursuit of commercial window design, in order to highlight its artistic charm and appeal to the greatest extent.

- Beauty of Space Image. Excellent window design not only displays the charm of good, but also indirectly tells the story to express the different artistic style and a broader cultural feelings.[3] Generally the size of commercial window area is not large, even minimal, but the tiny square of it always express of " seeing a world in a grain of sand" and the relaxed and happy image to customers "Fig. 2". Commercial window is composed of absolute space, exhibition space and space perception. The absolute space is the space occupied by the enclosed entity, which is the part of the indoor shopping mall and outdoor road corridor. It is the carrier of the window design, and has a strong limitation; exhibition space is the virtual physical space of enclosure through interface and props used for construct, launching ingenious display of commodity, with the help of the commodity, props and interface of the appropriate treatment, and the use of lighting, color and other elements to construct unique artistic effect by simulating the scene, the scale and proportion and symmetry and balance and other rules. Space perception is space exists beyond human body function, and it is resonate visual perception and psychological induction between customers and window space. These three are not alone in the construction of the building, but a complex. Space perception is the core of people, while the media elements are the external structure of the spatial order. Through the narrow window space, customers can feel the change of seasons, the years of circulation, the warmth of home, the hustle and bustle of the streets, the quiet night and other situations in life, not only can scrutinize to the micro of mustard, but feel the wide of the rivers and the height of mountains, germinating the aesthetic imagery of "a peak is a Chihiro Taihua, a spoon is a grand river."

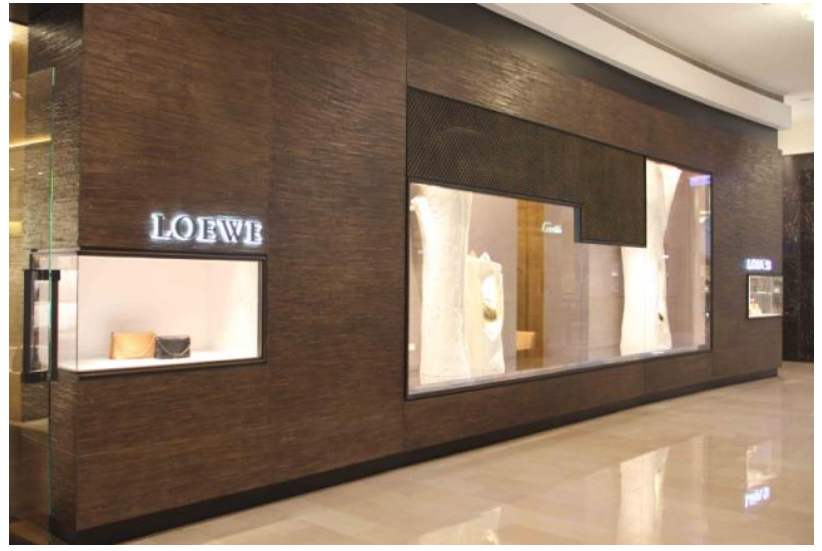

Fig. 2. Commercial Window's Beauty of Space Image

- Beauty of Creative Expression. Wen Qiuli, a postmodern architect, said "all the laws enacted by the people are limited, when the development of the situation and the law is in conflict, the law should be changed or abolished." With the high-speed push of market economy and fierce competition today, mediocre window design has been unable to meet the needs of the market, and people began to pursue fresh, stimulating and offbeat style of sensory information. Designers should do everything possible to achieve the personalized design to meet customers' needs of diverse forms of beauty, if designers blindly accept the designs since global modernization operated, it will step into the end of the road. This is actually a form of self exploration, self expression, confirmation of a form of self expression and values for designers. Using any method but not from the common rules of innovation is the general aesthetic characteristics of artistic creation, it also is a realm of commercial window design, the charm of window design thus produced "Fig. 3". Artistic expression and performance skills of commercial window design are in many aspects, multiangle. Personality in the design, style and design conception can enhance the implicit value of commodity, sending out the pure artistic charm in the colorful display, giving an infinite imagination and appeal, guiding customers to get visual, auditory, olfactory and tactile and other sensory information. Therefore, it can be said that creative expression of commercial window has leading aesthetic features. 


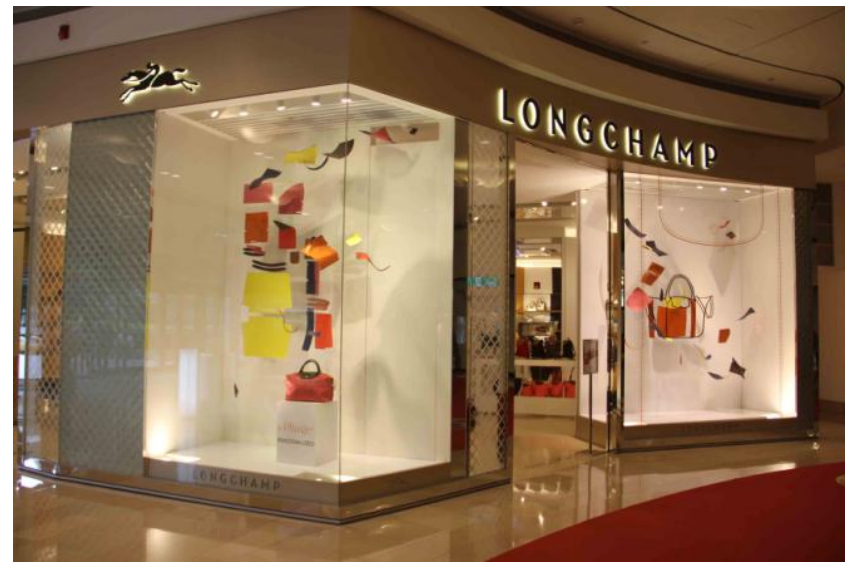

Fig. 3. Beauty of Creative Expression of Commercial Window

- Beauty of information presented. The window is in a given space of real product information transfer window, it can clearly identify the aesthetic features. In concrete design, recognition is through visualization technique to realize. It can through namely goods, logo, layout, text, images, graphics and other to show stores in the operation of the project and its connotation. And it can let customers fast and accurate identify of commodity information, make the shopping process easy and convenient, so as to shorten the shopping process, make the shopping psychology change from passive to active. Information's presentation of window design emphasis to close the specific recognition, and it's different from store and the long distance's overall recognition of construction. It will show store characteristics and personality to customers carefully elaborate "Fig. 4". Marked logo can make customers show the brand of goods without preamble, so that customers have a further understanding of the goods may be. Layout is one of the important elements of the current window design, and it involves two main contents about the plane and space.[4] flat content reflects the image and text layout to maintain the layout coordination; and in space stress the overall atmosphere of the visual effect of beauty, so that the interface and commodity, lights, props echoes, to attract customers in-depth understanding of commodity, and regulating the customer's watch mental state, so stores and commodity information can be fully show. Presenting information identification and creative expression induced in commercial window design is complementing each other and interaction. The identification leads induced, and induced increases recognition, so tow coordinated effect on customer psychological, to excited the customer's shopping desire, in order to promote the sale of goods.

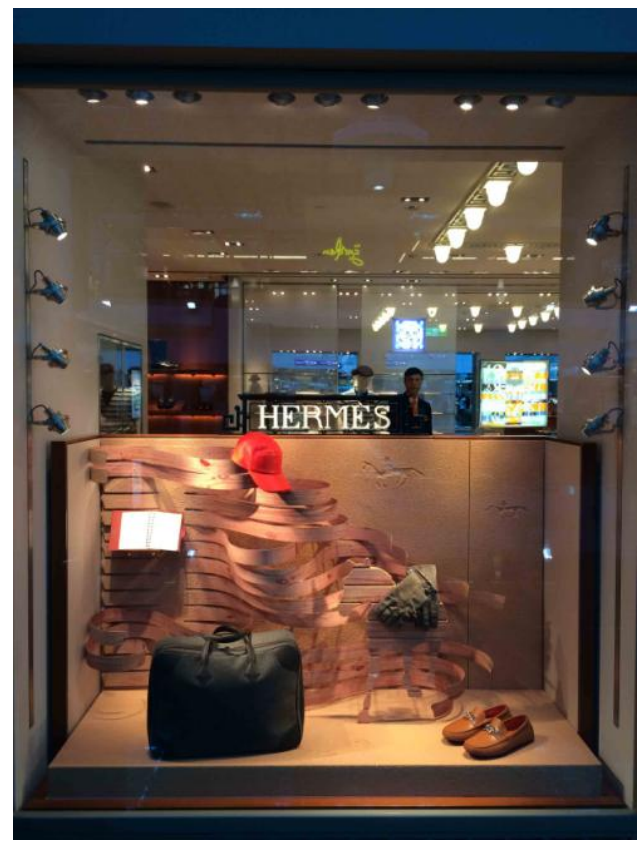

Fig. 4. Beauty of Information Presented

- Beauty of Environmental Dependence. Mies Van der Rhohe, a famous master architect, once said "The life of a city lies in detail." That is to say that the whole face of the urban environment is presented by the details of all aspects of the design, which can show a city's cultural taste and aesthetic taste. Therefore, the embodiment of the charm of the city should focus on the details, and the commercial window is the most important part of the city "Fig. 5". Exquisite and unique window design works can not only strengthen the urban individual image and highlight the city's cultural quality and aesthetic sentiment, but also is the core content of the construction of city image, and inclusive of the urban environment provides a stage to display their charm and character for window. Window is an independent individual with a unique personality, and it is also a part of entire commercial street and even part of the landscape of the city with some commons. Window designers should pay attention to the overall harmony and unity in the pursuit of individuality and changes, including the coordination with the landscape of the commercial district. It cannot ignore others to lose the harmonious beauty of the building's overall sense of unity and street landscape.[5] Commercial window has a unique personality, meanwhile it takes into account the harmony with the environment and unity, having the beauty of harmonious coexistence with the surrounding environment. 


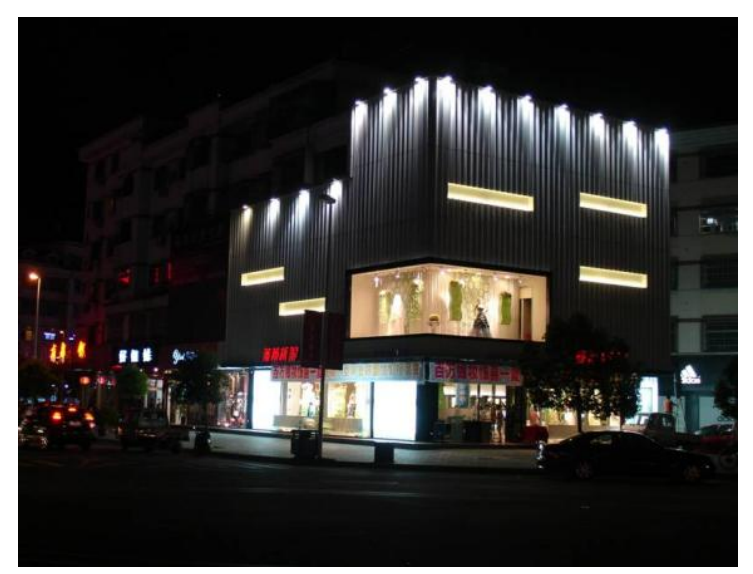

Fig. 5. Commercial Window's beauty of environment

\section{CONCLUSION}

Commercial window design is commercial and practical, and its ultimate goal is to maximize the appeal to customers and promote the sale of goods and get more profits. The nature and purpose of the aesthetic pursuit has potential constraints. In other words, commercial window design is a kind of art, but compared to others, its spiritual connotation is somewhat similarities and differences. The design art of the commercial window is mainly to please the customers and induce the customer to purchase, generally speaking, it stays in the visual aesthetic, and it is less deeply into the emotional and spiritual level. Therefore, the aesthetic pursuit of commercial window design should not only focus on the external visual form, but also should pay attention to the pursuit of its intrinsic humanities. The designer should follow the two aspects of the product material and spirit, grasping the aesthetic pursuit of the design of the window, creating a higher artistic level of the window image, in order to better highlight the charm and characteristics of the commercial window.

\section{REFERENCES}

[1] Ji Shuihe, Modern Decoration and Decoration Aesthetics [M] Wuhan: Wuhan University Press, 1995.

[2] Dan Xiaotong, On the Tendency of Modern Commercial Display Design [J] Packaging Engineering, 2011 (24).

[3] Gao Pin, Sun Shuang, Li Jun, The Style and Value of the Art of Window Advertising [J] Design,2015 (04).

[4] Huang Jiancheng, Space Display Design [M], Beijing: Peking University Press, 2013.

[5] Huang Juzhen, Store Design and Decoration [M], Beijing: China Building Industry Press, 1990. 